\title{
TAF7 wt Allele
}

National Cancer Institute

\section{Source}

National Cancer Institute. TAF7 wt Allele. NCI Thesaurus. Code C52609.

Human TAF7 wild-type allele is located in the vicinity of $5 q 31$ and is approximately $2 \mathrm{~kb}$ in length. This allele, which encodes transcription initiation factor TFIID subunit 7 protein, is involved in the mediation of the recognition of the transcriptional promoters for a variety of genes. 